NBER WORKING PAPER SERIES

\title{
BEYOND GOODS AND SERVICES: \\ COMPETITION POLICY, INVESTMENT, MUTUAL RECOGNITION, MOVEMENT OF PERSONS, AND BROADER COOPERATION PROVISIONS OF RECENT FTAs INVOLVING ASEAN COUNTRIES
}

\author{
O G Dayaratna Banda \\ John Whalley \\ Working Paper 11232 \\ http://www.nber.org/papers/w11232
NATIONAL BUREAU OF ECONOMIC RESEARCH
1050 Massachusetts Avenue
Cambridge, MA 02138
March 2005

This paper forms part of a wider project on the participation of the BRICSAM (Brazil, Russia, India, China, South Africa, ASEAN, and Mexico) countries in the global economy being supported by the Centre for International Governance and Innovation (CIGI), Waterloo, Canada. We are grateful to Ian McEwin, Rahul Sen, Shandre Thangavelu, and Ngee Choon Chia for discussions and suggestions. The views expressed herein are those of the author(s) and do not necessarily reflect the views of the National Bureau of Economic Research.

(C)2005 by O G Dayaratna Banda and John Whalley. All rights reserved. Short sections of text, not to exceed two paragraphs, may be quoted without explicit permission provided that full credit, including $\odot$ notice, is given to the source. 
Beyond Goods and Services: ASEAN Countries

O G Dayaratna Banda and John Whalley

NBER Working Paper No. 11232

March 2005

JEL No. F00, F02, F11, F15

\begin{abstract}
$\underline{\text { ABSTRACT }}$
We discuss recent bilateral, regional, and country trade, partnership, and economic agreements involving both ASEAN as a single entity and individual ASEAN countries (Singapore, Thailand, Malaysia) focusing on their reach beyond conventional trade in goods and services issues. What emerges is of a picture of ill-defined general commitments and precise undertaking, which vary from element to element and country pair to country pair. These agreements are recent, but they are numerous and more are under negotiation. We separately synthesize and evaluate provisions in five areas: competition policy, investment, mutual recognition, movement of persons, and broader cooperation.

O G Dayaratna Banda

Department of Economics

National University of Singapore

John Whalley

Department of Economics

Social Science Centre

University of Western Ontario

London, Ontario N6A 5C2 CANADA

and NBER

jwhalley@uwo.ca
\end{abstract}




\section{Introduction}

The recent wave of regional trade and other agreements that have occurred in the trading system, and been negotiated outside of WTO structure and process, have been noted in a number of recent papers (see, for example, Antkiewicz and Whalley 2004). Most of these agreements go substantially beyond conventional free trade agreements in dealing with items not yet subject to WTO disciplines and the idea that FTA's are still largely concerned with goods and services is no longer in keeping with contemporary realities. They have instead, like multilateral WTO negotiations, become platforms for packaging a range of new and ongoing issues previously dealt with separately (such as visas / work permits) into a combined negotiation. These issues, however, differ both between multilateral and regional negotiations, and across individual regional negotiations.

Indeed, the term FTA's is increasingly being displaced in negotiating circles by new language (for example, the recent Singapore-Japan agreement is a "New Age Economic Partnership"). Many of the recent regional agreements have long and complex texts, are relatively recent (last 2-3 years), with some scheduled for implementation over a period of 5-years stretching out around to 2010. More are under negotiation and the significance of regional agreements in the system will likely to grow.

The number and complexity of these agreements makes synthesizing their main features and understanding their implications for the trading system a non-trivial task. Here we discuss a subset of recent agreements both involving ASEAN as a single entity, and also those individual ASEAN countries negotiating separately as individual countries (Malaysia, Thailand and Singapore). ASEAN at this point has concluded three formal 
framework agreements (with China, Japan, and India) aiming to lead to move more substantive arrangements and has a further 2 (with Korea, and Australia \& New Zealand jointly) under negotiation. Singapore has concluded 6 substantive agreements (with the US, EFTA, Australia, New Zealand, Japan and Jordan) and is negotiating a further 12. Thailand has concluded 2 full agreements (with Australia, Bahrain), 2 framework agreements (with the US, India), 1 ancillary agreement to a wider ASEAN agreement only covering vegetable and fruits (with China), and is negotiating a further 5 agreements. Malaysia has a single bilateral investment treaty with the US, but is negotiating a further 5 agreements. These agreements vary greatly in length, specificity and coverage; some are lengthy and detailed with substantial specificity (especially the Singapore-US agreement).

Beyond the length and complexity of some of the agreements ${ }^{1}$, what is also striking is the breath of their coverage. Many areas beyond current WTO disciplines are dealt with including competition policy, mutual recognition (both of professional qualifications and product standards and testing), movement of persons and visa/work permit arrangements, investment, and cooperation in specific areas. Here we both summarize and interpret some of these elements and assess their impact. Whether these (and also other agreements outside of ASEAN) now represent a leading edge of globally negotiated new disciplines which is rapidly developing outside of WTO process is the broader issue on which our discussion touches.

Our assessment is that certainly the attention and detail devoted to these matters in pairwise agreements, some of which seemingly cover only relatively small amounts of

\footnotetext{
${ }^{1}$ By way of example, Singapore agreement with EFTA is 69 pages of text and 529 pages of annexes. The Singapore-US agreement is 240 pages of text with lengthy annexes treated as integral parts of the agreement.
} 
economic activity, support the notion something of substance has occurred in the areas we cover. Precedents for other agreements may be involved. The content of these agreements could thus well provide a future focal point for new attempts to deal with non-trade issues in subsequent more comprehensive agreement (visa and work permit issues is one example). Also, beyond the disciplines themselves, these agreements set in place institutional mechanisms outside of WTO process which will likely become increasingly significant for global trade policy management over the next few decades.

One can reasonably argue that these trade agreements are, for now, only vague and general statements of largely diplomatic significance, and also perhaps a response to a negotiating community seeking to achieve promotion both of itself and of individuals within negotiating bureaucracies. According to this view, these agreements, despite their length, should perhaps be seen as relatively lacking in force and hence symbolic and diplomatic rather than providing deeply substantive additions to WTO disciplines.

The position we argue in what follows is that there is substance in these agreements beyond goods and services (especially given slow progress multilaterally in the WTO), and more attention should perhaps be given to them by the research community. ${ }^{2}$ But at the same time, it is worth emphasizing that precise evaluation of their

\footnotetext{
${ }^{2}$ The recent literature discussing these agreements is limited and largely focused on the direct trade impacts from tariff barrier changes. DeRosa (2004) discuss both the ASEAN and individual country agreements, but almost exclusively in terms of their direct trade effects; issues beyond trade in goods and services are not centrally addressed. Weintraub(2004) compares the US, Chilean and Singaporean agreements, but once again does not touch centrally on the issues discussed here. A recent paper by Aoki (2004) discusses some of these issues in Japan's Economic Partnership Agreements, but does not discuss the full range of agreements we discuss here. The volume by Rajan and Sen (2001) and Sen (2004) provides background discussion for Singapore and ASEAN agreements, but with again little specificity on the issues addressed here. The paper by Gilbert, Scollay and Bora (2001) and the volume by Scollay and Gilbert (2001) also focus largely on the trade dimension of these agreements. Elek(2003) provides a general background discussion to the trading relationship behind these agreements, but little specificity on the issues touched here.
} 
impacts on global trade using analytical techniques of modern trade theory seems to us difficult to undertake.

We first briefly describe the recent regional and country agreements at issue, and then discuss their content in more detail for each of five areas beyond goods and services. These areas are competition policy, mutual recognition, movement of persons, investment, and broader cooperation provisions. In a concluding section, we provide an evaluation both of their significance in providing substantive new international disciplines and of their potential impact on the evolution of the wider trading system. 


\section{The Regional Agreements of Both ASEAN and ASEAN Countries}

The trade and wider economic partnership agreements of both ASEAN as a singe entity and individual ASEAN countries we discuss here are all relatively recent. ASEAN has concluded three agreements (China in 2002 with additional details agreed since; Japan in 2003; India in 2003), Singapore has six (New Zealand in 2000, EFTA in 2002, Australia and US in 2003, and Japan and Jordan in 2004), Thailand has four (with the US and Bahrain in 2002, Australia and India in 2003), and Malaysia has one (the US in 2004).All these entities are also currently involved in more negotiations. ${ }^{3}$

The agreements concluded thus far vary in coverage, specificity, and length. By way of example, the present US-Thai agreement is a framework agreement which acts as a precursor to a more substantial agreement and is a few pages and only establishes a joint consultative mechanism for future discussions and eventual negotiation. The USMalaysia agreement is similar in form, but restricted to investment. In contrast, the USSingapore agreement is 240 pages of text with lengthy annexes treated as integral parts of the agreement, and has 21 chapters. It covers trade in substantial detail, including a separate chapter on trade in textiles and apparel dealing with origin and transshipment. It also covers competition policy, mutual recognition in both services chapters, and chapters on movement of persons, investment, and many other issues. As the first of two of a recent wave of US bilateral agreements (along with Chile) (see Weintraub 2004) it had

\footnotetext{
${ }^{3}$ Singapore is negotiating a further 12 agreements with: Canada, Egypt, India, Korea, Mexico, Chile, Panama, Peru, Sri Lanka, Bahrain, Kuwait, and Qatar. Thailand is negotiating 5 with: Japan, China, Peru, New Zealand, and BIMSTEC. Malaysia is negotiating 5 with: Japan, New Zealand, Australia, India, and Korea. ASEAN is negotiating a further 2 arrangements with: Republic of Korea, and Australia \& New Zealand.
} 
significance as a precedent for subsequent regional negotiations for US groups with a wider interest in evolving US trade regime.

These agreements also differ substantially in coverage. The Thai-Bahrain agreement is a comprehensive trade agreement in its coverage of goods and services, but is largely restricted to this. The Singapore-Japan agreement, in contrast, is labeled a New Age Economic Partnership and has extremely broad coverage.

These agreements seemingly fulfill several roles. First, they allow for execution of customized and niche country (region) to country negotiations which differ case by case (unlike WTO agreements). This allows pairwise for countries to negotiate only on issues they jointly choose, and in ways they jointly select and so the form of each agreement pairwise differs. But they also provide for the development of country (region) to country relationships by establishing permanent and ongoing consultative and dispute settlement mechanisms. They also provide a forum into which discussions on existing non-trade issues can be brought for more comprehensive country to country negotiations (such as visas and work permit issues). They almost certainly respond to both political and bureaucratic internal demands within countries for negotiations which yield concrete agreements for public display, with resultant opportunities for advancement within negotiating bureaucracies. But at the same time, they are substantive since they also touch on a range of issues not yet covered by WTO disciplines, and hence potentially allow countries the opportunity to shape any subsequent multilateral disciplines through prior regional negotiations.

Some of the language in these agreements is vague and imprecise, and hence difficult to firmly evaluate, but in some areas the agreements are very explicit even with 
numerical targets specified for particular agreements. They have been little studied by the research community, because they are recent, diverse, and hard to quantify in terms of impact, but their potential significance for the evolution of the trading system, to us at least, seems not to be beyond doubt.

Table 1 lists these agreements. Singapore has been the most active of the negotiating entities involved, and also has generated the most complex and comprehensive of the resulting agreements. Singaporean policy is also now oriented towards the development of a network of negotiated economic relationships which seek to develop government to government partnership agreements well beyond the goods and services type agreements in the WTO and earlier FTA's and with many trading entities. Other ASEAN countries seem to be following the Singaporean lead with new country negotiations under way, although there is some debate as to whether other ASEAN countries will be able to move as quickly or as comprehensively as Singapore. Thailand is the country who has most comprehensively followed the Singaporean path, although the Philippines has a negotiation under way with Japan. 


\section{$\underline{\text { Table } 1}$}

$\underline{\text { Recent Trade and Economic Partnership Agreements of ASEAN }}$ and Individual ASEAN countries

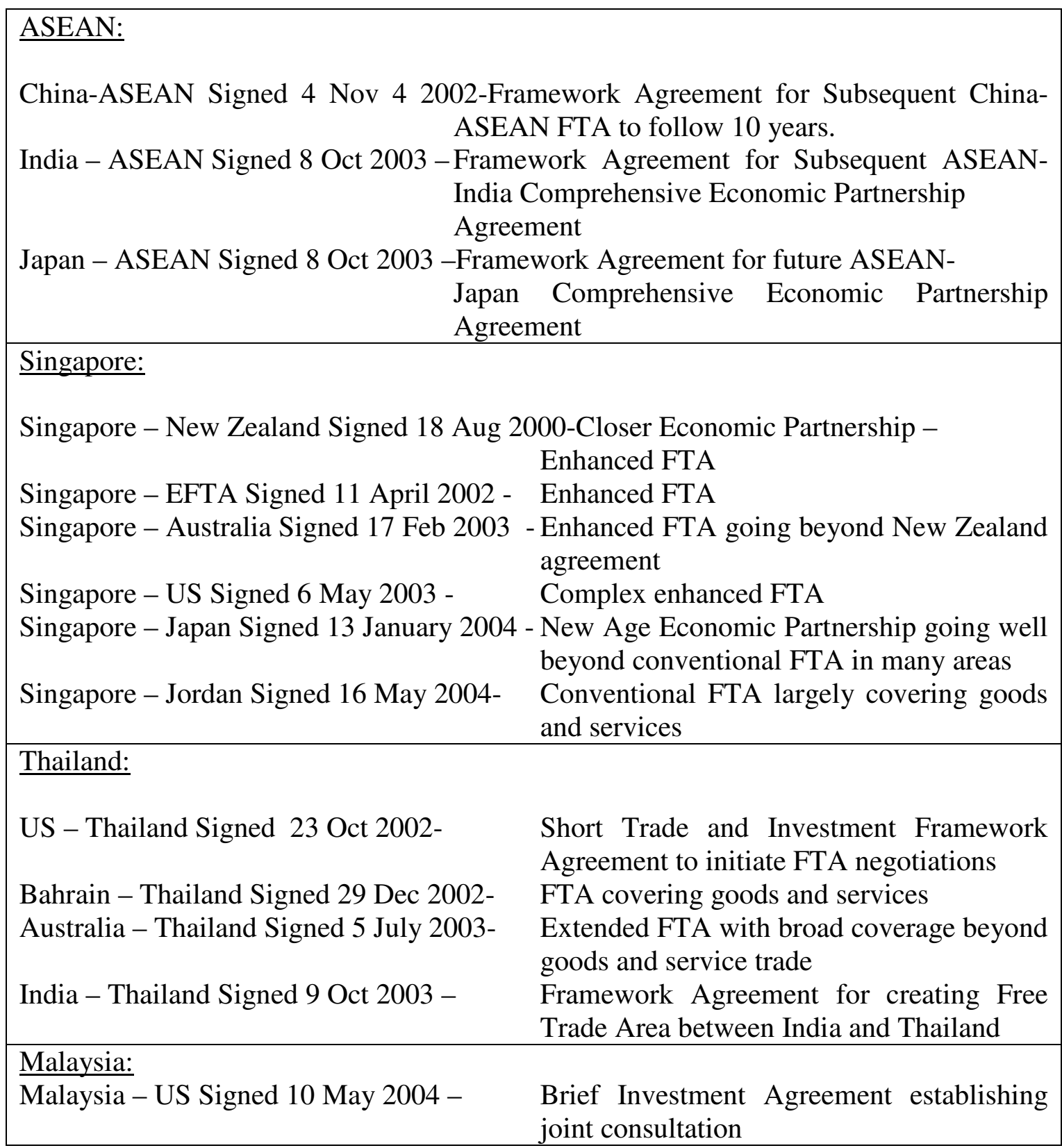




\section{Competition Policy}

The first of the areas beyond goods and services dealt with in the ASEAN and country agreements that we discuss is competition policy. The term competition policy captures laws and regulations that pertain to market conduct (abuse of market dominance), rights of entry, mergers and acquisitions, agreements between firms (including collusion behaviour) and abuse of market dominance, predatory conduct and other matters. Competition policies vary around the world involving both defined standards of conduct and performance with agencies to oversee these standards, and arrangements which grant firms rights to pursue civil actions. Many countries outside the OECD still have no competition laws. These policies are usually thought of as designed with an eye primarily to efficiency considerations (as currently in the US), but in some parts of the world (as in the EU) equity considerations also enter.

Of the ASEAN blocwide and regional agreements listed in Table 1, six of these contain provisions relating to competition policy; Singapore-US, Singapore-EFTA, Singapore-New Zealand, Singapore - Australia, Singapore-Japan, and Thailand-Australia. The two ASEAN agreements (with China and India) have no coverage of competition policy. Singapore at the time of negotiation had no formal competition law, but is now in the process of enacting such laws.

The ways in which competition policy is dealt within these agreements varies from case to case. The most detailed treatment occurs in the Singapore-US agreement, and is set out in a 8 page chapter (12) not titled competition policy but instead "Anti Competitive Business Conduct, Designated Monopolies and Government Enterprises”. This chapter commingles broad statements of principles on matters related to competition 
policy and detailed and specific commitments by the two parties on a range of competition related matters. Article 12.2 commits the two parties to adopt or maintain measures to limit anti competitive business conduct in their jurisdiction, and to each establish or maintain an authority within their countries to enforce such measures. No detailed list or elaboration of measures is given.

Article 12.3 goes on to define "designated monopolies" and "government enterprises", and specific commitments by each party with respect to each category follow. The government of Singapore, for instance, undertakes to act solely on the basis of commercial considerations in purchases and sales of goods and services involving government enterprises; not to enter into exclusionary or competition restraining practices with competitors, not to use voting rights to influence decisions of government enterprises in non commercial ways, and to have as a goal to eventually eliminate such aggregate ownership as confers effective influence over such entities. Singapore also commits to a detailed consolidated annual report for such entities identifying the percentage of shares owned by the government, a description of special shares or voting rights, the name and title of any government official serving as an officer, and annual revenues and/or assets. But the scope of the article is restricted in various ways. Price discrimination as a business practice, for example, is explicitly not covered by the article (and it is so stated), and nor are government procurement policies.

Articles 12.4 and 12.5 deal with cooperation and transparency, and parties commit to cooperate and make publicly available information requested of each other regarding such entities, relating to their business conduct considerations in their jurisdiction. Articles 12.6 and 12.7 set out consultation and dispute mechanisms. Article 12.8 then 
proceeds to areas of definition. Covered entities are defined to include entities under Singaporean laws in which the Government of Singapore owns special voting shares with veto rights with regard to a series of matters but excludes both government enterprises investing the reserves of the Singapore government in foreign markets, and Temasek Holdings (Pvt) Ltd, a holding company for government enterprises. Article 12.8 also sets out a definition of "effective influence" whereby the government and its government enterprises alone or in combination own more than $50 \%$ of an entity or have the ability to exercise substantial influence over the composition of the board of directors (or managing body). An annex (12A) sets out a flow chart providing an example of how effective influence may be interpreted in the implementation of the agreement.

The other agreements cover competition in less detail, but with some variation. The Thai-Australia agreement commits both governments to actually apply their competition laws, but allows measures or sectors to be exempt from the commitment on public interest grounds if done on a transparent way. There are then (undetailed) commitments to cooperate and exchange information, to consult, and to make publicly available their respective competition laws.

The Singapore-Australia agreement is similar but goes further. Parties commit to promote fair competition, and to curtail four types of anti competitive practice. These are anti-competitive horizontal arrangements between competitors; misuse of market power, including predatory pricing by business; anti competitive vertical arrangements between businesses; and anti competitive mergers and acquisitions. They also agree to promote competition, and to apply their competition laws under a principle of "competitive neutrality" under which no competitive advantage is to accrue to government and 
business because they are government owned. A statement of allowable exemptions (similar to the content of the Thai- Australia agreement) follows, along with commitments to consultation, review and transparency.

The Singapore-EFTA agreement is even shorter, comprising 11 lines of text (in chapter 10). Parties accept that anti competitive practices can impact on trade, and agree upon request to enter into consultation and provide information which is confidential to business interests. The parties then have recourse to arbitration under this chapter.

The Singapore- New Zealand agreement is even shorter than the SingaporeEFTA agreement with five lines of text in Article 24. The joint commitment is that both parties will ensure that where specific commitments are made relating to market access and national treatment for goods and services that they are not adversely affected by actions of a monopoly supplier.

The Singapore- Japan agreement is a little longer with 3 articles, but is still brief. It states that each country is free to use its own competition laws. It then states the willingness of the two governments to cooperate in controlling anti competitive practices, without providing details of the cooperation. It then indicates that dispute settlement arrangements in the wider agreement will not apply to this part of the agreement.

These agreements though varied are not lacking in specificity as far as competition law is concerned (especially the Singapore -US agreement) and they also need to be seen alongside other efforts to generate systems of international disciplines over domestic competition laws. Perhaps the most far reaching of these are in the EU, where diverse domestic laws of member states have been overlaid with commonly 
accepted European wide statutes with European courts with powers to levy fines and other penalties.

The competition policy component of these agreements can also be seen as a partial bilateral response to the failure in the WTO to negotiate on competition policy. In the WTO these was considerable discussion of competition related issues following the 1996 Singapore ministerial and prior to the launch of the Doha Round. As Bhattacharjea (2004) identifies, the directions proposed for a multilateral agreement in competition policies in these discussions included achieving investment promoting benefits of harmonized competition policies; actions against anti competitive practices that restrict market access for imports; replacement of anti-dumping arrangements by competition policies (as in the EU); and restrictions on cross border cartels. In the 2001 agreement to launch the round only part of this list survived, and this remaining part was then dropped at the 2004 Cancun ministerial (see Bhattacharjea 2004).

Relative to these efforts, what is both sought and achieved in these country agreements is more modest. Harmonization of competition policy is not accepted as a goal, but weakening the trade effects both of competition policies and anti competitive practices do represent a clear objective. There is no uniform approach, sharp differences also occur in the specificity and precision of some agreements (Singapore-US) relative to the generality of others. But there is substance in the provisions in this area. 


\section{Investment Provisions}

Investment is dealt with in more of the country agreements than is competition policy and is also covered in the ASEAN agreements. There is also more commonality in approach, with central commitments being (either or both) National Treatment and MFN treatment for foreign investors (typically) alongside provisions relating to expropriation, compensation, and (in some cases) repatriation of earnings.

The ASEAN agreements deal with investment briefly and only in generalities. The ASEAN - Japan and ASEAN - India agreements are virtually the same and contain general commitments to create a liberal and competitive environment for investment, to strengthen cooperation in investment, improve transparency of laws and regulations, and to protect investors. The ASEAN-China agreement has similar general provisions, but the language differs.

Among the Thai agreements, the Thai-US agreement is brief in stating agreement to enter consultations with a view to negotiations between the parties, but both trade and investment are mentioned. The bilateral Thai-India agreement reiterates the content of ASEAN - India agreement. The Thai - Bahrain agreement commits parties to create favourable conditions for investors and to collaborate through joint ventures.

The Thai-Australia agreement is more comprehensive with 11 pages of text in its investment chapter. It begins with definitions but then centers its liberalization commitments on most favoured nation treatment for investors, with separate "preestablishment" and "post-establishment" national treatment provisions. ${ }^{4}$ There is then

\footnotetext{
${ }^{4}$ The rationale for these two separate commitments as against a single national treatment commitment is not clear to the present authors.
} 
language relating to the promotion and protection of investments, and provisions relating to expropriation and compensation for losses as well as access to dispute settlement.

Among the Singaporean agreements, the US-Singapore agreement is lengthier and more detailed (31 pages in the investment chapter), but follows a similar flow to the ThaiAustralian agreement above. It has both national treatment and most favoured nation treatment for investors of the other party as central commitments. There is then an agreed minimum standard of treatment as fair and equitable treatment under customary international law, but with little specificity as to terms. It then proceeds to provisions regarding expropriation and compensation. It commits parties to freely allow transfers related to investments. It jointly removes all performance requirements relating to investment regulation, and finally commits that senior management of a covered investment can be of any nationality. It concludes with Investor-State Dispute Settlement procedures.

The Singapore-EFTA agreement has 7 pages of text in its investment chapter and covers similar matters using more general language. Most favoured nation and national treatment stand as central commitments. There is an article on taxation, applying national treatment and most favoured nation treatment also to taxation of investment. Provisions on expropriation and compensation follow with an article permitting domestic regulation of investment on safety, health, or environmental grounds. Articles on transfers and mobility of personnel follow.

The Singapore -Australia agreement has 12 pages in its chapter on investment. This differs from the others agreements in only having national treatment (not also most 
favoured nation) as the central commitment. ${ }^{5}$ Further departures from other agreements include a specific chapter on transitional provisions on regional government measures, and safeguard escape provisions for movement of persons commitments for balance of payments purposes explicitly set out in the investment chapter.

The Singapore-Japan agreement is lengthier and more detailed. It takes national treatment as the central commitment. It prohibits performance requirements, and covers expropriation and compensation. It has an article on the repurchase of leases. It then covers transfer and dispute settlement. The Singapore-New Zealand agreement has five pages of text covering both most favoured nation and national treatment as joint commitments, and an article on repatriation and convertibility. Finally the Malaysian US agreement is a brief 2 page document with a commitment to consult and eventually negotiate in the investment area.

These agreements show much more commonality of approach on investment than is case of competition policy. There are substantive commitments, and interestingly of relatively similar form to those proposed for the failed Multilateral Agreement on Investment. In this area, regional negotiations clearly seem to be fulfilling the role of a partial substitute for a wider multilateral agreement between countries who were not (in the main) forces of resistance to an agreement on multilateral disciplines eventually emerging from the WTO.

\footnotetext{
${ }^{5}$ Since no border is involved with customs clearance with investment flows (unlike goods), it would seem that all that is required is national treatment (a commitment that foreign and domestic investors receive equal treatment). This raises the issue of why other agreements contain two (National Treatment and MFN) commitments, rather than one.
} 


\section{Mutual Recognition}

The coverage of issues related to mutual recognition in the agreements listed in Table 1 lies in a number of chapter headings in the various texts. Issues of product testing and product standards arise in chapters on technical barriers to trade and sanitary and phytosanitary restrictions, and particular sectoral chapters, such as on telecommunications touch on product standards, while chapters on services deal with recognition of professional certification. This treatment of mutual recognition differs substantially from the explicit country pairwise treaties on mutual recognition that have been negotiated in recent years. These typically involve both mutual agreement to accept agreed competent authorities for the mutual determination of standards, and agreements on the mutual recognition of more narrowly specified items (such as notorial attestations, or certificates).

The US-Singapore agreement contains several mutual recognition elements. Chapter 6 indicates steps to implement Phase I and Phase II of the APEC Mutual Recognition Agreement for conformity Assessment of Telecommunications Equipment. Chapter 6 also establishes a working group on medical products providing a forum for bilateral cooperation on product regulation issues of mutual interest.

Chapter 8 on services covers both domestic regulation of qualification requirements and procedures and technical standards and licensing, requiring that these not constitute unnecessary barriers to services trade. It then moves on to the issue of recognition, indicating that recognition of education or experience obtained, or licenses or certificates, may be achieved by harmonization and provides general principle as to how such harmonization may be negotiated. An annex to the chapter sets out more detail 
on how professional standards should develop on a mutually acceptable basis in more detail.

Recognition issues also arise in chapter 12 which covers Temporary Entry of Business Persons. Section IV relating to short term entry arrangements for professionals commits each party to grant entry to professionals in categories entered in an Appendix, provided that the persons involved possess appropriate credentials. The appendix then lists two professions (disaster relief claims adjusters and management consultants) and sets out the maximum educational requirements and credentials for each.

The Singapore-Japan agreement, in contrast, contains a separate chapter on mutual recognition, which effectively takes the form of a bilateral mutual recognition treaty but now located in a wider economic partnership agreement. The chapter discusses the designation of conformity assessment bodies and conformity assessment procedures for products and processes and provides definitions. Parities are to ensure that the designating authorities have powers to designate, monitor, and to change designations of bodies, and then proceeds to articles detailing verification and monitoring of conformity assessment bodies. The chapter establishes a joint committee on mutual recognition as the institutional structure, with procedures for the registration of conformity assessment bodies. The agreement also contains an Article on mutual recognition of professional qualifications in the chapter on movement of natural persons, and establishes a joint committee on such mutual recognition.

None of the ASEAN agreements touches on mutual recognition issues, and among the Thai agreements only the Australian agreement does. In separate chapters on industrial technical barriers to trade, and sanitary and phytosanitary measures and food 
standards, there are articles on harmonization and equivalence of industrial standards, and conformity assessment procedures. The chapter on sanitary and phytosanitary measures and food standards establishes a bilateral consultative forum on these matters.

The Singapore-Australia agreement, in contrast to the others, explicitly states as its objective to build on the preexisting mutual recognition agreement on conformity assessment between Australia and Singapore. In its chapter on technical regulations and sanitary and phytosanitary measures it sets out scope and obligations and states harmonization to be the objective. It sets equivalence of mandatory requirements as a goal, and lists a series of cooperative activities on sanitary and phytosanitary /quarantine matters. These include conformity assessment and exchanges of information and consultation.

The Singapore-New-Zealand agreement also has broad coverage of mutual recognition in its chapter on technical, sanitary and phytosanitary regulations and standards. It begins by defining both mutual recognition and unilateral recognition, and establishes a work programme, including in the specific area of electrical and electronic equipment. It then has chapters on mutual recognition of equivalence of mandatory requirements, mutual recognition of conformity assessment, mutual recognition of equivalence of standards, and exchange of information.

Beyond competition policy and investment, these agreements thus also touch centrally on issues related to mutual recognition. It some cases (Singapore-Japan) they allow for what is in effect a comprehensive mutual recognition treaty to be embedded in the wider economic (or trade) agreement. In other cases (Thai-Australia) they extend existing mutual recognition agreements. In others (Singapore-US) they set out detailed 
commitments in a number of areas which implies concrete mutual recognition commitment. 


\section{Movement of Persons}

The ASEAN blocwide and country agreements also deal with issues related to movement of persons, usually in separate chapters. This is reflective both of the growing significance of visa and work permit issues in the global economy and the absence of multilateral venues for dealing with them (see $\mathrm{Ng}$ and Whalley 2004). ${ }^{6}$ In this case, country or regional agreements provide the platform for adding an issue under current discussion, but with no clear multilateral forum for discussion. Bargaining across issues and with it, the greater probability of achieving results presumably provides the rationale for this.

The Singapore-US agreement has a separate chapter on movement of persons (chapter 11) with 11 pages of text and annexes devoted to this issue. Interestingly, it begins with a broad statement that the preferential trading relationship between the parties implies a mutual desire to facilitate comparable temporary entry with transparent criteria and procedures. It then proceeds to a general obligation to apply measures in the area so as to avoid adverse impacts or delays involving trade in goods and services or the conduct of investment activities under the agreement. There are then provisions on information exchange, transparency criteria and an agreement to appoint temporary entry coordinators in each country.

The detailed substance in the chapter occurs in an annex (11A) which sets out details of arrangements under four section headings; business visitors, traders and investors, intra-company transfers, and professionals. In some cases, (such as business visitors) it sets out required documentation for entry. In other (professionals) there are

\footnotetext{
${ }^{6}$ Also, see Nielson (2002) for a recent discussion of temporary movement of persons in other recent bilateral agreements.
} 
appendices which set out numerical target for initial applications for entry of business persons from Singapore that US shall annually approve $(5,400)$. These also specify a number of considerations required by US immigration laws can that the US shall not take into account when making entry visas. These are specific detailed concessions to Singapore on these matters.

Movement of persons is also dealt with in other agreements, but in more generality and less specificity. The Singapore-Australia agreement is limited to movement of business persons, with detailed definition, of key terms including "business visitors", "immigration formality", "intra-corporate transfers", "service sellers", "short term service sellers" and "temporary entry". There are then explicit commitments to facilitate both "short term temporary entry" and "long term temporary entry", information exchange, and dispute settlement.

The Thai-Australia agreement is similar, but definitions and terms vary slightly. "Contractual services supplier" is defined, but does not appear in the Singapore-Australia agreement, for instance. Commitments on short term temporary entry and long term temporary entry are also the central commitments here.

In contrast, the Singapore-EFTA agreement is more limited in scope. There is no chapter explicitly on movement of persons, but in the investment chapter of the agreement there is an article (45) granting entry to investors and key personnel involved with investments. The Singapore-New Zealand agreement, equally, has no chapter on movement of persons, but it does have separate article with this title in part 11 on General Provisions. This involves a general undertaking by parties not to apply measures restricting movement, and indicates that the parties may subsequently negotiate specific 
commitments. The Singapore-Japan agreement does contain a separate chapter (9) on movement of persons. There are specific commitments set out in an Annex for short term visitors and intra corporate transfers. There are then both provisions on and a joint committee devoted to mutual recognition of profession qualifications. Neither the ASEAN nor the shorter framework agreements contain provisions relating to the movement of persons.

That there is content in these agreements also in the area of movement of persons seems clear, although both the approach and the specifics vary case by case. Here, seemingly, the presence of the platform provided by a wide ranging trade and economic partnership agreement facilitates visa and work permits issues being included in the negotiations. But, the diversity of both outcome and approaches makes the emergence of later common disciplines from these agreements that much more difficult to envisage. 


\section{Broader Economic Cooperation}

In addition to the specific areas of coverage set out above, these agreements also contain a range of commitments relating to cooperation in a number of areas. Cooperation agreements are typically vague in statement, and it is often tempting to dismiss them as lacking in substance. But they do represent a commitment to a deepening of bilateral relationships and do so in specific and designated areas and hence are of substance from a process point of view. The stress on cooperation in the China-ASEAN agreement is also manifest in the title of the agreement as a "Framework Agreement on Comprehensive Economic Cooperation" indicating the significance attached to cooperation in bilateral relationship building in this case.

The widest ranging cooperation commitments occur in the ASEAN-China agreement. There are commitments to strengthen cooperation in 5 key sectors (agriculture, information and communication technology, human resource development, investment, and Mekong River basin development). Concrete measures to strengthen cooperation are to be worked out in such areas as standards through conformity assessment, technical barriers to trade, customs cooperation, promotion of electronic commerce, and technology transfers.

The ASEAN agreement with Japan and India also details many areas of cooperation including trade facilitation, business environment, energy, information and communications technology, human resource development, tourism and hospitality, transportation and logistics, and standards conformity and mutual recognition. Nether the Singapore nor Thai more detailed agreements, nor the shorter Thai framework 
agreements contain cooperation agreements, with the exception that the Thai-India agreement contains language similar to that in the Thai-ASEAN agreement.

Though inevitably vague and hard to interpret as legal text, these cooperation elements in these agreements play a role as process in the deepening of country to country relationships. For countries where sequential relationship building and deepening is seen as a critical way to proceed in international negotiations, the cooperation provisions of these agreements can play a major role as process as far as international economic management is concerned. Commitments to cooperate, even if ill defined, are part of process and these new partnership agreements unlike traditional tariff based trade agreements are not typically negotiated typically as one off treaty arrangements by countries with an exclusive focus on legal provisions and detailed text. There are also symbolic trust building arrangements, involving symbolic and relationship reinforcing exchange. 


\section{The Implications for the Wider Trading System}

Our paper discusses the broad, diverse, and in some cases concrete commitments which are manifest in recent regional agreements involving both ASEAN as a bloc and individual ASEAN countries in a range of areas beyond WTO disciplines. Given that more of these agreements are under negotiation and agreements outside of the ASEAN are also growing rapidly in number and form, it seems worthwhile to make some comments on what we see as the implications for the wider trading system. This is still today, despite difficulties in the WTO, seen as centrally a multilateral rule based regime to which regional WTO plus type arrangements are appended. We would not claim that the WTO is being replaced regional arrangements, but their number and scope do suggest that increasingly the system is one of blended regional and multilateral disciplines.

The component of these agreements we discuss here involves the emergence of a system of disciplines covering non-WTO issues. In some cases where failed negotiation occurs at multilateral level (as in investment), these regional negotiations seem to be partially filling a void. In other cases, the presence of events and importance of the issues ((movement of persons) is producing a different response pairwise. While this seems to be happening in a somewhat inconsistent manner across the various pairwise cases, these agreements can only lay the foundation for an eventual set of uniform disciplines that can be multilateralized with some difficulty.

The role that the bilateral trade or partnership agreement in each case plays seems to vary from case to case. Competition policy and investment negotiations both partially fill voids left by failed multilateral negotiations. Mutual recognition negotiations allow existing agreements to be elaborated on in a broader bargain with linkage to other issues. 
Movement of persons allows for the platform of a wider economic partnership agreement to be used to bring ongoing policy discussion into a larger package of negotiation. And cooperation agreements represent a commitment to ongoing process in relationship building sequential negotiation.

These agreements also provide the opportunities for bilateral pairs to customize their agreement to the bilateral propensity as to how to proceed. The commonly stated concern with such agreements is the erosion of multilateral disciplines via a cluster of regional agreements and the complexity and administrative difficulties they generate (in rules of origin and pairwise dispute settlement for instance). But, if one argues that there are gains from bargaining, just as there are gains from trade, then bilateral bargaining free of the constraints of multilateral rules which restrict bargaining (as in the WTO) may offer more opportunities for mutual gain. The outcomes discussed here, it can be argued, in part facilitate this through the coverage of for now non-negotiable multilateral issues.

Our discussion also seemingly points to the evaluation that just as at multilateral level, what are labeled as trade agreements are ever more in reality becoming more than conventional tariff based agreements covering only trade in goods and services. Both multilaterally and regionally, trade policy is increasingly linked to an ever growing number of issues and an ever changing structure of wider global economic management. This structure may seem opaque, a little chaotic, and hard to evaluate; but the reality would seem unavoidable.

For many years with the successes of the GATT in the Dillon, Kennedy, and Tokyo Rounds in achieving significant reductions in tariffs on manufactures in the OECD, it was argued both that trade rules should be separated from other policy elements 
so as to preserve a liberal trade regime as a key motor for global growth and that the GATT allowed this. The linkage multilaterally first to intellectual property in the Uruguay Round, and then later as proposed to environment, labour standards, and other issues has thus been a subject of much debate and apprehension from trade policy practitioners and researchers.

At regional level we seemingly now have indications of considerably wider and more extensive linkage. The fear of contamination of trading arrangements and possible increases in trade barriers driven by cross retaliation has in practice to be counterbalanced by the potential increase in gains from bargaining by expanding the bargaining set. And the practical reality is that all issues are inevitably linked through the political process.

These ASEAN blockwide and country regional agreements simply serve to underscore all these trends. Global trade policy is now inextricably linked to non-trade issues; it is somewhat chaotic and (in places) highly non transparent and hard to evaluate using analytical models. It is ever more diverse, and difficult at times to synthesize and distill. In the areas we discuss, we would repeat our comment earlier that these agreements merit more attention. 


\section{Conclusions}

We discuss recent bilateral, regional, and country trade, partnership, and economic agreements involving both ASEAN as a single entity and individual ASEAN countries (Singapore, Thailand, Malaysia) focusing on their reach beyond conventional trade in goods and services issues. These agreements are recent, but they are numerous and more are under negotiation. We separately synthesize and evaluate provisions in five areas; competition policy, investment, mutual recognition, movement of persons, and broader cooperation. What emerges is of a picture of ill defined general commitments and precise undertaking, which vary from element to element and country pair to country pair, but there can be little doubt as to the presence of substance, which in turn, seemingly grows in complexity and form in more recent agreements.

We suggest in concluding comments that though difficult to analyze through analytical methods used by economists, their presence in the trading system may be increasingly hard to ignore. A linked WTO and non-WTO (or regional network) of trade treaties would seem to define the contemporary world, with difference in coverage and treatment between the two. In this set of agreements, international negotiation founded on mutual tariff concessions on goods and later enlarged to services in the GATS seems now to be inextricably linked to a wider range of issues now facing inter-country economic management. This reality of the contemporary trading system seems clear in what we discuss. 


\section{References}

Antkiewicz, A. and J. Whalley (2004), "China's New Regional Trade Agreements" NBER Working Paper No. 10992.

Aoki M. (2004) "New Issues in FTAs: The Case of Economic Partnership Agreement between Japan" APEC Study Centers Consortium Meeting, March, Chile.

Bhattacharjea, A. (2004) "Trade and Competition Policy", Working Paper No 146 Indian Council for Research on International Economic Relations, Delhi.

DeRosa P. (2004) "US Free Trade Agreements with ASEAN" in ed., J Scott Free Trade Agreements: US Strategies and Priorities, Institute for International Economics, Washington DC.

Elek A. (2004) "Beyond Free Trade Agreements: $21^{\text {st }}$ Century Choices for East Asian Economic Cooperation" Pacific Economic Papers No 336, Australian-Japan Research Center.

Gilbert J., R. Scollay and B. Bora (2001) “Assessing Regional Trading Agreements in the Asia-Pacific" Policy Issues in International Trade and Commodities, Study Series No 15, UNCTAD.

Nielson, J. (2002), “Current Regimes for Temporary Movement of Service Providers: Labour Mobility in Regional Trade Agreements," Joint WTO-World Bank Symposium on Movement of Natural Persons (Mode 4) under the GATS, 11-12 April 2002.

Ng E. and J. Whalley (2004), "Visas and Work Permits: Can GATS/WTO Help or is a New Global Entity Needed?" (mimeo). 
Rajan R. S. and R. Sen (2001), Singapore Free Trade Agreements: Economic Relations with Japan and the United States, ISEAS, Singapore.

Rajan R. S. and R. Sen (2004), "The New Wave of FTAs in Asia: with particular reference to ASEAN, China and India" (mimeo)

Schott J. ed., (2004) Free Trade Agreements: US Strategies and Priorities, Washington, DC: Institute for International Economics.

Scollay R. and J. Gilbert (2001), New Regional Trading Arrangements: in the Asia

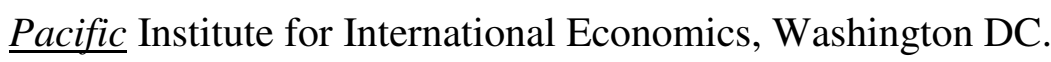

Sen R (2004) "Free Trade Agreements in Southeast Asia" Southeast Asia Background Series No. 1, Institute of Southeast Asian Studies.

Weintraub S. (2004) "Lessons from the Chile Singapore Free Trade Agreements" in ed., J Scott Free Trade Agreements: US Strategies and Priorities, Institute for International Economics, Washington DC. 